\title{
Flensborg-spørgsmålet \\ i Den nordslesvigske Vælgerforenings tilsynsråd 1918-19
}

\section{Af Troels Fink}

\section{Indledning}

Da det sønderjydske problem blev aktuelt efter Tysklands nederlag i 1918, fik Den nordslesvigske Vælgerforening, de danske sønderjyders organisation, en meget stor betydning. Den var organiseret således, at den havde en meget lille bestyrelse på kun tre mand og et stort tilsynsråd, der med suppleanter udgjorde ca. 60 personer. De var valgt i valgkredse i forhold til medlemstallet, således at hele Nordslesvig, inklusive Flensborg og omegn, var dækket. Vælgerforeningens tilsynsråd blev en slags privat parlament. Det vedtog $\mathrm{i}$ nov. $1918 \mathrm{og} \mathrm{i}$ de følgende måneder en række resolutioner der fik vidtrækkende betydning, ikke mindst den grundlæggende resolution af 17. nov. 1918.

I min skildring "Da Sønderjylland blev delt 1918-1920« har jeg nærmere gjort rede for, hvorledes problemerne blev behandlet her, men det har vist sig, at nogle finder at Flensborgproblemet ikke har fået tilstrækkelig alsidig dækning. Jeg vil derfor gerne gå noget nærmere ind på den måde, hvorpå Flensborgspørgsmålet blev behandlet i Den nordslesvigske Vælgerforenings tilsynsråd fra nov. 1918 til dec. 1919.

Den ledende sønderjydske politiker var i denne periode $H$. P. Hanssen. Han foreslog, at Nordslesvig skulle stemme under ét, enbloc, som man sagde. Der er ingen tvivl om, at han i okt. 1918, ikke havde tiltro til, at Flensborg kunne komme med til Danmark, altså hvis selvbestemmelsesretten skulle ske fyldest. Den 9. nov. 1918 skrev han til næstformanden, P. Grau: "Det gør ondt at prisgive Flensborg, men vi må se ædrueligt på forholdene. Gustav Johannsen, som kendte byen nøje, havde prisgivet den i 1896, da jeg blev hans kollega i landdagen “; og H. P. Hanssen sluttede: "Jeg tror at vi kan opnå denne grænse [altså den nuværende], og at ingen sydligere grænse selvfølgelig bortset fra enkelte landsbyer - vil kunne give os en tryg national fremtid . 
Denne lille antydning: "selvfølgelig bortset fra enkelte landsbyer « blev måske en tilskyndelse til, at $\mathrm{P}$. Grau begyndte at tænke på de "tilstødende distrikter“. Da Vælgerforeningens repræsentanter for Sønderborg amt holdt møde den 11. nov. vedtog de en tilføjelse til H. P. Hanssens program om afstemning i Nordslesvig under ét: "En selvfølge anser vi det for at være, at hvis tilstødende distrikter syd for denne grænselinje ved en særskilt afstemning tilkendegiver ønsket om at komme til Danmark, disse da skal have lov til at udøve deres selvbestemmelsesret".

Der er nogle, som er af den opfattelse, at forslaget om enbloc-afstemning $\mathrm{i}$ Nordslesvig var et middel til at holde Flensborg uden for det nordslesvigske område, som man ellers siden 1867 havde regnet Flensborg med til, og at det var urimeligt, at Flensborg i nov. $1918 \mathrm{ikke}$ blev inddraget under 1.zone, der skulle stemme under ét.

Det rejser så spørgsmålet: hvorfor blev Flensborg ikke taget ind i 1.zone? Med den viden, man dengang havde, er svaret ret enkelt: Så ville det hele være sat på spil!

\section{Stemmetallene ved valget i 1912 og deres betydning}

Ved vurderingen af det nationale styrkeforhold gik man ud fra det senest afholdte rigsdagsvalg. Det var holdt i januar 1912. Det havde været et godt valg for de danske. "Flensborg Avis" skrev: "Den 12. jan. 1912 har været en stolt dag i den sønderjydske danskheds historie. Befolkningen vil beholde sin hånd på ploven og styre fremover med arbejdsmod og fremtidshåb.« Fremgangen lå i Nordslesvig og i Oversø sogn syd for Flensborg. Men i Flensborg by så det ikke godt ud: 5421 stemte på tyske borgerlige partier, 5691 på socialdemokraterne og 456 på den danske kandidat. Det var en fremgang for de danske siden sidste valg på 34 stemmer, men modstanderne var ialt gået frem med 1856 stemmer. Det danske stemmetal svarede til knap $4 \%$ af de afgivne stemmer.

Det var på denne baggrund, mange 1918 anså Flensborg by for »tabt «. Men Tysklands sammenbrud skabte også i Flensborg et stærkt røre. Advokat Chr. Ravn, der var medlem af Vælgerforeningens tilsynsråd, rettede den 13. nov. en opfordring til bystyret om at sørge for, at Flensborg under alle omstændigheder bevarede forbindelsen med Nordslesvig, også hvis dette blev indlemmet i Danmark. Den 12. nov. skrev Vælgerforeningens næstformand, P. Grau, i »Flensborg Avis« at den danske befolkning i Nordslesvig med glæde ville se Flensborg som Nordslesvigs hovedstad komme tilbage til Danmark. Men han tilføjede: »Ingen af os vil have Flensborg til at være os 
følgagtig mod sin vilje. Ingen ønsker grænsen trukket syd for Flensborg, hvis flertallet af Flensborgs indbyggere protesterer derimod."

Tager man Nordslesvig under ét, blev der i 1912 afgivet 16645 danske stemmer og 9660 tyske, men lægger man dertil stemmetallene for Flensborg forandres billedet: så er det danske tal 17101, men det tyske 20772. Efter det tyske nederlag i 1918 kunne man måske nok regne med en vis forskydning $\mathrm{i}$ dansk favør. Men ingen turde løbe risikoen, heller ikke tilsynsrådets to repræsentanter for hhv. Flensborg og landdistrikterne, advokat Ravn og gårdejer P. Budach. Resolutionen om at der skulle stemmes i Nordslesvig under ét blev enstemmigt vedtaget. Ravn og Budach gjorde en tilføjelse: "Undertegnede tiltræder foranstående resolution, men med det forbehold, at Flensborg efter vor mening hører med til Nordslesvig, omend ikke til det danske Nordslesvig «. Meningen med disse ord er vel netop den erkendelse, at Flensborgs tyskhed kunne vippe resultatet $i$ tysk favør, og derfor ville de to ikke tage ansvaret for at kræve Flensborg føjet ind $i$ enblocområdet.

Man kan ikke hævde, at det kun var ugunstige forhandlingsvilkår der førte til den valgmåde, der blev fulgt i 1918. De to, der kom med deres særvotum, har bestemt ikke villet skade arbejdet for at få Flensborg til Danmark, men de forstod, at for Flensborgs vedkommende måtte sagen afgøres ved en særskilt afstemning. Herom var alle Flensborgs talsmænd ved denne lejlighed enige; de gik også ud fra at afstemningsresultatet skulle være afgørende for byens skæbne.

Spørgsmålet om Flensborgs stilling må dog også bedømmes på den baggrund, at der ved afstemningerne i 1920 viste sig en så stor national forskydning, at stemmetallene for Nordslesvig og Flensborg under ét gav stort dansk flertal: 84375 danske mod 52301 tyske stemmer, men når man skal vurdere situationen i nov. 1918 er dette selvfølgelig uden betydning.

Ejheller er der styrke i den argumentation, at det var ulogisk, at Flensborg, som både i 1867 og i 1920 havde større dansk stemmeandel end Tønder, måtte udelukkes fra Danmark på grund af selvbestemmelsesretten, når Tønder kom med. Nej, det ulogiske i forhold til selvbestemmelsesretten ligger deri, at Tønder blev inddraget $\mathrm{i}$ 1.zone. Meningen med afstemning under ét $\mathrm{i}$ hele Nordslesvig var at undgå enklaver (man regnede med at Åbenrå og Sønderborg ville møde med tysk flertal) og dels at sikre Tønderhjørnet for Danmark. Der kunne anføres gode økonomiske og geografiske grunde derfor; men vi må klart erkende, at en udligning i dansk favør på Tønderegnen var sikret på forhånd.

Når enbloc-bestemmelsen for Nordslesvig blev fastholdt, havde H. P. Hanssen intet imod, at der blev en særskilt afstemning i Flensborg. Resolutionen af 17. nov., der gik ud fra enbloc-afstemning i Nordslesvig og 
kommunevis afstemning i tilstødende distrikter, blev loyalt respekteret af alle parter i den følgende bevægede tid. Men den endelige afgørelse lå hos sejrherrerne i 1. verdenskrig. Det var dem der skulle forhandles med, og det måtte den danske regering gøre.

\section{Tilsynsrådets resolutioner om afstemningsfrihed og stemmeretsregler}

Den 30. dec. 1918 vedtog tilsynsrådet en supplerende resolution. Den lød: "Idet Den nordslesvigske Vælgerforenings bestyrelse og tilsynsråd på ny har fastslået en løsning af nationalitetsspørgsmålet i Sønderjylland på grundlag af folkenes selvbestemmelsesret som svarende både til ret og billighed for begge parter og som stemmende overens med de anskuelser, der næres af det store flertal inden for den sønderjydske befolkning, udtaler den samtidig folgende:

1. Vi nedlægger en skarp protest imod, at man fra de tyske magthaveres side $\mathrm{i}$ Mellemslesvig søger at hindre den derværende danske befolkning i, gennem en fri udøvelse af forsamlings- og petitionsretten, at skabe grundlaget for en fri afstemning.

2. Vi fastslår, at gennem ovennæunte fremgangsmåde fra tysk side er selvbestemmelsesretten foreløbig gjort illusorisk for det danske Mellemslesvigs vedkommende.

3. Vi henstiller til den danske regering, når den varetager vore interesser ved fredskonferencen, at gøre opmærksom på, at den danske befolkning i Mellemslesvig under disse forhold ikke kan håbe på at opnå sin nationale ret ved en folkeafstemning.«

Resolutionen var foreslået af A. Svensson, og den pegede på det alvorlige problem, hvorledes afstemningsfriheden kunne sikres. Noget konkret forslag i så henseende indeholdt den ikke, og man måtte vel regne med, at de påpegede ulemper kunne afbødes. Der var i resolutionen ejheller taget stilling til den eventualitet, der begyndte at optage sindene: en tvivl om der overhovedet ville komme en afstemning! Resolutionen af 30. dec. blev af den danske regering tilstillet repræsentationen i Paris på linje med Vælgerforeningens ovrige resolutioner.

Spørgsmålet om sikring af afstemningsfriheden var nok under alle omstændigheder blevet rejst, men rent konkret var det altså sket ved den nævnte resolution. Der forelå flere muligheder: enten en militær besættelse eller oprettelse af et særligt politikorps eller eventuelt en aftale med den tyske modpart. 
Den danske udenrigsminister, Erik Scavenius, havde store betænkeligheder ved en militær besættelse: fra tysk side ville man senere kunne hævde, at afstemningen var foregået under tryk. Han mente, at en evakuering af tysk militær og en tysk-dansk kommission med svensk eller norsk opmand ville kunne lose problemet.

Til at begynde med var H. P. Hanssen og hans folk af samme opfattelse, men de ledende danske i Mellemslesvig, der havde problemet nærmere inde på livet, bragte den 8 . feb. 1919 spørgsmålet frem i Vælgerforeningen tillige med en række andre emner.

Et af disse emner var en udløber af den såkaldte første Flensborgbevægelse, der byggede på den eventualitet, at der ikke blev afstemning. I jan. 1919 havde dette spørgsmål optaget sindene stærkt: hvad med Flensborg, hvis der ikke bliver afstemning? Flensborg-bevægelsen fremsatte krav om, at Flensborg i så fald burde komme med til Danmark, men regeringen ville kun modtage Flensborg efter en folkeafstemning. Vælgerforeningen vedtog så 8 . feb. en kompromisresolution, hvori det hed, at man anså det "som givet, at Flensborg ikke udelukkes fra Danmark, inden den under frie forhold har haft lejlighed til at fremkomme med tilkendegivelser, som derefter danner grundlaget«. Denne resolution kunne regeringen godkende, hvis de omtalte tilkendegivelser måtte kunne erstatte en folkeafstemning efter princippet om selvbestemmelsesretten. Resolutionen fik kun teoretisk interesse, for rygterne om, at der ikke blev folkeafstemning, var grundløse.

Det skal her lige indskydes, at den danske regering selvfølgelig stod frit overfor Vælgerforeningens resolutioner. Regeringen var ikke et ekspeditionskontor for Vælgerforeningen. I sidste instans var det regeringen, der var ansvarlig for den politik, der fra dansk side blev ført i Paris.

Mere betydningsfuld var indholdet af den anden resolution, der blev vedtaget den 8 . feb. 1919. Ernst Christiansen foreslog, at der skulle vedtages særlige stemmeretsregler for Mellemslesvig. Det betød afvigelse fra de regler, der var vedtaget 17. nov. 1918. Her var det besluttet, at stemmeretsalderen skulle være 20 år, og at tilflyttere skulle have haft bopæl $\mathrm{i}$ afstemningsområdet i mindst 10 år for at få stemmeret. Nu vedtog man for Mellemslesvig 25 års valgretsalder, og bopælskravet blev udvidet til 1. jan. 1900. Det betød, at færre af de tilflyttede, fortrinsvis tyske, fik stemmeret, en klar fordel for den danske side.

Til betryggelse af afstemningsfriheden vedtog man desuden følgende udtalelse: "Afstemningsområdet må, for at en blandet kommission [dvs. blandet dansk-tysk kommission med svensk eller norsk opmand] kan betrygge et frit oplysningsarbejde, besættes af neutrale tropper mindst seks uger, forinden afstemningen finder sted, og samtidig må den udøvende magt 
fratages de hidtilværende forvaltningsmyndigheder «.

Det nye her var kravet om militær besættelse af Mellemslesvig med neutrale tropper. Det må her fastholdes, at resolutionen kun gjaldt Mellemslesvig. Når der tales om "afstemningsområdet“, er det det område $\mathrm{i}$ Mellemslesvig, hvor der skulle være kommunevis afstemning. Da H. P. Hanssen sendte denne resolution til udenrigsministeren, bad han ham forelægge den for fredskonferencen som et fyldigt udtryk for de ønsker, der blev næret af den danske befolkning i Flensborg og Mellemslesvig.

\section{Kompromis med den danske regering om afstemningsregler}

Man kan undre sig over, at en så kyndig politiker som H. P. Hanssen ikke kunne se, at man umulig kunne have forskellige afstemningsregler for Nordslesvig og for Mellemslesvig, derimod kunne man nok have forskellige regler om eventuelle besættelsestropper. Udenrigsministeren sendte ikke denne resolution til Paris. Den indgik derimod i de overvejelser, der nu blev aktuelle, om at sende en delegation til Paris, bestående af danske og slesvigske politikere. Når en fælles delegation skulle afsted, måtte den nødvendigvis være enig. Det hastede med at få delegationen afsted, hvis den ikke skulle komme for sent; arbejdet med at nå til enighed foregik under et stærkt pres. Jeg skal ikke her komme ind på det problem, der har været fremme i diskussionen: om H. P. Hanssen kunstigt og af taktiske grunde fremkaldte et tidspres; overvejelserne vedrørende kravet om ensartede afstemningsregler foregik på et møde den 22. febr., hvor de tre mænd $i$ bestyrelsen for Valgerforeningen kom sammen med Ernst Christiansen. Her blev man enige om et kompromis: i begge afstemningsområder fik kun tilflyttere, der var kommet før 1. jan. 1900 stemmeret, en markant fordel for den danske side. Kravet om militær besættelse blev formuleret således, at der kom til at stå »den danske befolkning i Flensborg og Mellemslesvig og vide kredse i Nordslesvig holder det for nødvendigt, at Flensborg og Mellemslesvig besættes med neutrale tropper mindst seks uger før afstemningen finder sted «.

I forhold til det forslag om indsættelse af en blandet kommission og om rømning af tysk militær, der tidligere var fremsat af udenrigsministeren, var der gjort en meget væsentlig tilføjelse. Det hed: "Samtidig indsættes der en blandet kommission, som er udrustet med tilstrækkelige magtmidler til at sørge for, at oplysningsarbejdet kan foregå frit og uforstyrret, så at en retfærdig afstemning kan finde sted«. Tilføjelsen byggede på en passus $i$ et brev, udenrigsminister Erik Scavenius havde sendt til H. P. Hanssen med et krav om ensartede regler. Han skrev: "Medens den danske regering er af den 
opfattelse, at der bør indsættes en blandet kommission for at overvåge, at en for begge nationer retfærdig afstemning kan finde sted, og at der til rådighed for den bør stilles tilstrækkelige magtmidler til hævdelse af dens autoritet, nærer regeringen store betænkeligheder ved en militær besættelse «. Spørgsmålet var altså, om afstemningsfriheden skulle garanteres med et stærkt politi eller ved militær besættelse. I realiteten var det et forslag til at løse problemet om sikring af afstemningsfriheden $i$ Vælgerforeningens resolution af 30. dec. 1918.

Mødet er ganske kort omtalt i Vælgerforeningens protokol, og her siges det at $H$. P. Hanssen den følgende dag ville overgive den nye affattelse til det danske udenrigsministerium. Men den danske udenrigsminister var syg; i hans sted fungerede forsvarsminister P. Munch, og med ham havde H. P. Hanssen den 23. febr. et møde. Det holdtes hos professor Aage Friis, der var en ven af $P$. Munch. Tilstede var også Nis Nissen. I politisk henseende var det P. Munch og H. P. Hanssen, der betød noget. Om mødet har P. Munch gjort et notat: "Vi aftalte, at de sidste ændringer i Aabenraaresolutionen om afstemningsreglerne måtte ændres endnu mere, navnlig således at området, hvorfra man skulle være flyttet til afstemningsområdet, måtte være alle fem amter«. Det vil sige, at alle tilflyttere fra Haderslev, Åbenrå, Sønderborg, Tønder og Flensborg amter fik afstemningsret.

\section{Kompromissets konsekvenser og godkendelsen i tilsynsrådet}

Det er blevet hævdet, at denne ændring betød en forringelse af de danske chancer i Flensborg, idet tilflyttere fra Angel derved ville få stemmeret. I forhold til de mange der mistede stemmeret ved reglen om 19 års bopæl, er det små tal, der kan være tale om derved, at der skulle gives valgret til tilflyttere fra oplandet. Flensborgs skæbne blev ikke sat på spil ved denne ændring. Forslaget om de fem amter må også ses i lyset af, at man ikke på det tidspunkt havde en klar afgrænsning af, hvad Mellemslesvig var. Det fik man nu. Det var området mellem Clausen-linjen og disse amters sydgrænse. Man regnede desuden med, at der endnu kunne komme petitioner med ønske om at deltage i en afstemning, men man må forstå forholdet således, at ønskerne måtte komme fra kommuner nord for disse amtsgrænser. Der blev yderligere givet den indrømmelse, at afstemningen i Mellemslesvig skulle være vejledende, altså ikke følges $i$ et og alt.

Alle disse overvejelser er kun af teoretisk interesse, for i Paris var linjerne allerede lagt ind i det spor, der førte til det endelige resultat: besættelse med allierede tropper og oprettelse af en 2.zone. Den kendte man ikke $i$ København på det tidspunkt. I Paris skete også ved en fejl den ændring, at alle 
der var født i de to zoner fik valgret, uanset bopæl. Denne fejl fik senere vidtrækkende konsekvenser.

Men tilbage bliver spørgsmålet: Kunne bestyrelsen ændre en vedtagen resolution, og kunne formanden gå med til et kompromis om de fem amter uden først at forelægge sagen for tilsynsrådet som den kompetente forsamling?

H. P. Hanssen var inde på problemet i den redegørelse, han gav til tilsynsrådet, inden han rejste med delegationen til Paris. "Vi havde konstateret, at bestyrelsen ikke formelt var berettiget til at ændre de af fællesmøderne vedtagne beslutninger vedrørende afstemningsreglerne af 17 . nov. og 8. feb. men var derefter blevet enige om, at vi kunne anbefale et forslag som P. Grau eller Ernst Christiansen antagelig vil kunne forelægge foreningen«. Om den sidste ændring skrev han: "Det var imidlertid klart at vi, hvis enighed skulle opnås, måtte gøre en indrømmelse med hensyn til fødsel indenfor de fem nordslesvigske amter i stedet for nord for afstemningslinjen som betingelse for stemmeret. For dette forslag kunne vi håbe at vinde støtte hos Alexander Foss og I. C. Christensen imod regeringen og Bramsnæs. Dette slog også til.«

H. P. Hanssen har ikke udtrykkelig nævnt, at dette kompromis blev forberedt på et møde med P. Munch og Nis Nissen hos Aage Friis; men hvor mange kompromisser er ikke forberedt på tilsvarende måde! Kompromisset blev først endeligt indgået, da delegationen til Paris holdt møde den 25. febr. og Flensborgbevægelsens repræsentanter, Kloppenborg Skrumsager og Andreas Grau gik med til det. Ernst Christiansen var hoppet fra forliget og havde meddelt det til Kloppenborg Skrumsager, der imidlertid bøjede sig til sidst.

De sønderjydske delegerede: H. P. Hanssen, Kloppenborg Skrumsager, Nis Nissen og Andreas Grau var ganske klart gået ud over Vælgerforeningens resolution og forliget af 22 . feb. for at opnå enighed med den anden part, nemlig regeringen og partierne bag den. Men resolutionen af 8 . feb. betød en ændring af det tidligere accepterede grundlag og derfor kunne regeringen stille betingelser for at gå med til ændringer; det kunne socialdemokraterne også. Det lykkedes at nå et kompromis, der gav væsentlige fordele til de danske i Flensborg i forhold til det oprindelige grundlag fra 17. nov.

Efter almindelig og demokratisk fremgangsmåde måtte de sønderjydske delegerede søge at få godkendt deres afvigelse fra mandatet på næste tilsynsrådsmøde. Det holdtes den 1. marts 1919, men da var delegationen på vej til Paris. Problemet blev grebet an på den måde, at protokollen fra aktionsudvalgs-mødet den 19. feb. og bestyrelsesmødet den 22. feb. blev læst op; bankdirektør R. P. Rossen ønskede en protest ført til protokols, som 
skulle behandles på det følgende møde. Næstformanden P. Grau forsvarede fremgangsmåden og henviste til den korte frist, der havde gjort det nødvendigt at handle hurtigt. Man enedes om at udsætte spørgsmålet til næste møde, dog først efter at delegationen var vendt hjem fra Paris.

Denne forudsætning var opfyldt da næste møde blev holdt den 27. marts. Protokollen fra 1. marts blev læst op, men det problem, som R. P. Rossen havde ønsket drøftet, blev tilsyneladende ikke berørt i forhandlingen. Hvad angår $\mathrm{H}$. P. Hanssens beretning om rejsen til Paris står der i protokollen: "Denne udmærkede, her i korte træk skitserede redegørelse fra formanden modtoges med tilfredshed og vandt tilsynsrådets udelte bifald.« H. P. Hanssen havde fået tilgivelse.

Det problem, om fødested i de fem amter, som havde voldt så store kvaler før delegationen rejste, var forsvundet af sig selv, fordi delegationen i Paris blev orienteret om det forslag til 2. zone, som $\mathrm{H}$. V. Clausen havde udarbejdet. Ingen skænkede længere forslaget om fødested i de fem amter som betingelse for stemmeret en tanke. Der skulle gå 60 år, før det blev draget frem som noget væsentligt.

\section{Skal stemmerne tælles eller vejes?}

Flensborg-mændene havde ved forslaget til fredstraktaten fået alt, hvad de havde ønsket: militær besættelse og 19 års grænse for tilflytteres valgret. Bevægelsen kunne regne med omfattende støtte til agitationen. Ikke desto mindre kom det i sommeren 1919 til en heftig indbyrdes strid mellem de danske.

Det skyldtes, at fredsforslaget indeholdt en bestemmelse om, at der også skulle stemmes i en 3.zone. Det blev kendt i maj 1919. Det var Danevirkebevægelsen, der havde opnået dette resultat. I striden om 3.zone støttede Flensborg-mændene i Vælgerforeningen Danevirke-bevægelsen. De følgende debatter i tilsynsrådet, i maj, juni og juli, gjaldt 3.zone, og senere, da den var bortfaldet som afstemningszone, ønsket om at få området rømmet for tysk militær og tyske embedsmænd.

Disse debatter gik så dybt, at tilsynsrådet blev sprængt. Anledningen var formelt et krav om nyvalg til tilsynsrådet. Det lykkedes at kitte revnen og nyvalg blev fastsat til 30. nov. 1919. Forinden havde tilsynsrådet afsluttet rømningsdebatten ved den 18 . okt. at vedtage en resolution, hvori man bad Den internationale Kommission om, når den fremsatte sit forslag, at tage hensyn til den moralske og reelle virkning på 2.zone af, at 3.zone ikke blev rømmet. Det blev af Flensborg-folkene opfattet som en udstrakt hånd fra Åbenrå-retningen. 
Valgkampen i nov. 1919 var bevæget, for at sige det mildt. Den var kendetegnet ved, at især statsminister $\mathrm{C}$. Th. Zahle var skydeskive for Flensborg- og Danevirke-folkene. Formålet var ganske klart at drive en kile ind mellem ham og H. P. Hanssen, der i sommeren 1919 var blevet medlem af Zahles regering. Oppositionen håbede at skaffe sig et flertal i tilsynsrådet, så H. P. Hanssen kunne få et mistillidsvotum; dermed ville bunden være slået bort under hans ministerpost; man kunne så håbe, at regeringen Zahle ville blive draget med i faldet. Det var strategien.

Den taktiske ammunition fandt man i en tale, som Zahle havde holdt den 9. nov. i Ringsted. Zahle stod på det standpunkt, at Flensborg kun kunne komme til Danmark, hvis flertallet ønskede det. Året før havde det været det almindelige standpunkt, men nu gav hans tale anledning til heftige angreb, ikke så meget det principielle standpunkt, men man kritiserede, at han ikke havde taget stilling til Vælgerforeningens opfordring til Den internationale Kommission om at tage hensyn til de reelle og moralske følger i 2.zone af at 3.zone ikke var blevet rømmet. Desuden kritiserede man, at han den 9. nov. ikke havde taget afstand fra en tale, som den tyske rigskansler Gustav Bauer nogle dage i forvejen havde holdt, og hvori han havde sagt at Flensborg var en gammel tysk by og at Tønder måske kunne reddes for Tyskland og endelig, at han havde søgt at foregribe Den internationale Kommissions afgørelse.

I rigsdagen søgte Zahle den 18. nov. at råde bod på forsømmelserne. H. P. Hanssen fik lejlighed til at se Zahles manuskript forinden. Han forsøgte at få ændret en passage, hvori Zahle ville sige, at det ikke kunne være meningen, at afstemningen i Flensborg ikke skulle "respekteres«. H. P. Hanssen foreslog i stedet ordene "tillægges vægt «. Zahle mente, at der heri ville være en tendens til at stemmerne skulle vejes, ikke blot talles, og det var utvivlsomt også H. P. Hanssens mening. H. P. Hanssen stod ikke stift på det af ham foreslåede udtryk, men det var klart, at han og Zahle så forskelligt på vurderingen af det kommende resultat.

Af valgkampen til tilsynsrådet fremgik det klart, at Åbenrå-retningen ikke ubetinget ville stå på kravet om absolut flertal for at Flensborg kunne komme til Danmark. Men det blev under valgkampen klart, at Flensborg-retningen nu krævede 2.zone til Danmark uanset afstemningsresultatet; det ville Åbenrå-retningen ikke være med til.

Efter nyvalget 30. nov. 1919 bevarede H. P. Hanssen flertallet i tilsynsrådet. Det var blevet lidt mindre, men mest fordi Flensborg havde fået flere repræsentanter som følge af stor medlemstilgang. I Nordslesvig var forskydningerne små. Den 13. dec. 1919 holdt tilsynsrådet møde; her fik H. P. Hanssen det tillidsvotum, der gjorde det muligt, at han kunne fortsætte som minister, og som forlængede regeringen Zahles liv med et par måneder. 
På mødet 13. dec. spurgte A. Svensson, om H. P. Hanssen forud havde haft lejlighed til at tage stilling til Zahles tale. H. P. Hanssen svarede, at han stod fuldstændig uafhængigt inden for ministeriet; svaret på spørgsmålet kunne fås ved at drage en sammenligning mellem hans og Zahles udtalelser.

Det er blevet hævdet at H. P. Hanssen stod som sønderjydsk kautionist for regeringens politik, og når han ikke kunne påvirke statsministerens formuleringer, måtte han hæfte for dem eller gå. Det er et meget hårdt krav, for i det store og hele var $H$. P. Hanssen og Zahle enige i den opfattelse, at selvbestemmelsesrettens princip skulle følges, således at afstemningsresultatet måtte lægges til grund for grænselinjen. Men fremfor alt var situationen ikke akut; afstemningen lå endnu flere måneder ud i fremtiden. Først når den havde fundet sted var der en anledning til at tage endelig stilling. Der var ikke stof til et kabinetsspørgsmål i den divergens, der var mellem H. P. Hanssen og Zahle.

Der var nemlig en forskel i $H$. P. Hanssens og Zahles synspunkter, men som medlem af regeringen måtte Hanssen naturligvis tage rimelige hensyn ved formuleringer heraf. Mere frit kunne hans tilhængere markere deres stilling. Under valgkampen havde Åbenrå-retningens repræsentanter alle givet udtryk for, at de ikke mente, at det absolutte flertal skulle være afgørende for Flensborgs skæbne, forudsat at der fremkom et stort dansk mindretal over for et lille tysk flertal, altså f.eks. $47 \bmod 53 \%$.

\section{Et sidste forsøg på at ændre afstemningsreglerne - resolutionen den 13 . dec. 1919}

Hvad det nærmere skulle betyde fik man klarhed over, da tilsynsrådet den 13. dec. enstemmigt vedtog en resolution af følgende indhold: "Den bestemmelse, at enhver der er født i afstemningsområdet har stemmeret, var tænkt som en styrkelse af den indfødte befolkning; men det har vist sig, at den, som folge af særlig Flensborgs hurtigt skiftende befolkning navnlig gennem embedsmændene og militæret, giver tyskheden en tilvækst af stemmer fra valgere, der ikke står $i$ anden forbindelse med landet end gennem deres tilfældige fødsel engang for 20 år siden.

Vælgerforeningen retter derfor til de sejrrige allierede og associerede magter den indtrængende bøn: Hvis en revision af fredstraktaten viser sig mulig, gives artikel 109, punkt 2 , litra $b^{1}$ i fredstraktaten den i den danskslesvigske delegations indstilling formulerede ordlyd: At de er født og hjemmehørende $\mathrm{i}$ afstemningsområdet (også når de midlertidig har taget ophold i udlandet) eller har boet i 20 år eller er blevet udvist. 
II. Hvis en revision af fredstraktaten ikke kan opnås (at de allierede og associerede magter da) ved opgørelsen og vurderingen af afstemningsresultatet ikke vil tillægge denne tilvækst af stemmer fra fuldstændig landsfremmede elementer samme vægt $\mathrm{og}$ betydning som de af den bosiddende og i landet hjemmehørende befolkning afgivne stemmer «.

Kort fortalt betød denne resolution, at Åbenrå-retningen var rede til at råde bod på den fejl, der var sket, da valgretsreglerne blev udformet, hvorved alle $\mathrm{i}$ området fødte, uanset bopæl, havde fået stemmeret. D.v.s. hvis de tilrejsende stemmer var blevet udslaggivende for afstemningsresultatet, så var Åbenrå-retningen rede til at anbefale Den internationale Kommission at se bort fra de tilrejsendes stemmer.

Hvordan Zahle ville have stillet sig til denne mulighed, kan vi ikke vide; den indtraf aldrig. Resultatet af afstemningen i Flensborg blev 25\% danske stemmer af alle valgberettigede; hvis de tilrejsendes stemmer trækkes fra, var resultatet blevet $28 \%$ for Danmark.

Efter mødet den 13. dec. 1919 mistede vælgerforeningens tilsynsråd sin betydning. Ser vi på forløbet, hvad Flensborg-spørgsmålet angår, var der af Åbenrå-retningen givet den ene indrømmelse efter den anden, men alt under fastholdelse af selvbestemmelsesrettens princip.

Resolutionen af 18. okt. om at tage hensyn til den manglende rømning af 3.zone blev som næunt af Flensborg-retningen opfattet som en udstrakt hånd. Det blev resolutionen af 13. dec. ikke, for kampagnens egentlige mål: at vælte H. P. Hanssen, var ikke lykkedes. Flensborg-folkene nærede en tyrkertro på, at blot Zahle kom væk, ville alt blive godt. Så enkelt var det ikke. I fredstraktatens bestemmelser var tingene lagt i så faste rammer, at der kun var ringe spillerum for en dansk regering, hvordan den end var sammensat, fremfor alt: Frankrig og England så forskelligt på sagen, men det er, som man siger, en anden historie. 